\title{
INDUSTRIAL PARKS - HISTORY, PRESENT AND ITS INFLUENCE TO THE
} EMPLOYMENT

\section{Jarmila Vidová}

Katedra hospodárskej politiky, NHF EU v Bratislave, Dolnozemská cesta 1, 85235 Bratislava 5; e-mail: vidova@dec.euba.sk

\begin{abstract}
The term industrial park is currently a very frequently used. One of the conditions of their development is a positive trend of capital movement and correct allocation of capital in new conditions of Slovak and world economy. In current postindustrial stage of development, industrial parks grow in quality in comparison of parks built in the past when all the activities of product building were allocated were concentrated into one single place. The new generation of industrial parks is characteristic by producing just one product or completion of final goods from components. The present day development in Slovakia confirms that it is necessary to support creation of industrial parks because it has a positive influence to activities supporting research and development and increasing of employment.
\end{abstract}

Key words: investment, industrial park, employment.

JEL Classification: E22, E23, 016.

DOI: $10.2478 / \mathrm{v} 10135-009-0008-1$

Národohospodářský obzor - Review of Economic Perspectives ISSN 1804-1663 (Online), ISSN 1213-2446 (Print)

http://nho.econ.muni.cz/en

(C) Masarykova univerzita 


\section{INDUSTRIAL PARKS - HISTORY, THEIR PRESECE AND INFLUENCE ON EMPLOYMENT}

\section{Jarmila Vidová ${ }^{1}$}

\section{Introduction}

A change of the status of economies, caused by globalisation of economies in the world, is and important and prominent feature of current development. The pressure on structural adaptation in the area of production, investment and business is a common feature of global economics development. On the basis of experience and know-how of the most developed European and world's countries, we can see that creation of capital resources and ways of their use are some of the most crucial and important questions of economical progress sustainability and flueency of structural-adaptation processess in an economy, fundament of which dwells in capital valorization, factor of production mobility, creation of international subjects and development of industrial parks. In Slovakia, industrial parks represent an opportunity for an influx of foreign investment and decrease of unemployment rate by the means of creation of new jobs.

This article focuses on history, fundamentals and the meaning of creation of industrial parks in Europe in theory and practice. The influence of industrial parks on unemployment rate will be shown on the example of Slovakia.

The theoretical definition of the term "industrial park" and the historical background of their development

Industrial parks are one of the most important factors supporting positive economy development. An industrial park is based on a philosophy of integration of relatively different functions (production function, and that of services, relaxation and education, too) into an industrial area with majority of industrial production and services with high economy turnover and high employment. It provides services independent of type and importance of a particular industrial park, i. e. standard and non-standard services. The examples of standard services are finance and law consulting, accounting, security of assets, operation and support of a transportation and technical infrastructure environment or public greenery support. Non-standard services, provided mainly in parks with country-wide and international importance with higher number of subjects, include logistic services, technology transfer, procurement of research and development services, financial services, banking, agency and leasing of educated workforce, human resource services, food courts and housing, sport, publication of periodicals and different information bulletins about industrial park, organizing of various events, classes and lectures for managerial positions, as well as for employees of companies from park, and", as last but not least, a support of network cooperation between other industrial parks administrators, too.

An industrial park as such is characterized by a united conception, unique and highly particular configuration, selection of production units and overall area maintenance. It is

1 Ing. Jarmila VIDOVÁ, Ph.D., Katedra hospodárskej politiky, NHF EU v Bratislave, Dolnozemská cesta 1, 85235 Bratislava 5; e-mail: vidova@ dec.euba.sk 
based on integration of different functions of research, production, education that take place in the particular industrial area.

In Slovak literature, the term "industrial park" is basically very similar to the name of "industrial district", production zone or production cluster. Nonetheless, English economic literature uses terms such as industrial estate, trading estate, factory estate, or employment areas (Keppl, 2001). An industrial park is defined as an area reserved for industrial development which is usually located close to the transportation environment, mainly in case where more types of transportation are used. A "light version" of an industrial park is then an "Office Park"; this term is used when the objects described are mainly offices for light industry. The idea of industrial park development was based on several principles which most of all included allocation of specialized infrastructure in selected areas with the aim of decreasing costs connected to building infrastructure, and, furthermore, capability of a country to attract new investors, which would eliminate social and ecological impacts caused by industrial production.

When it comes to industrial parks, we could also mention Burgess' Theory of concentric zones. It was coined by Ernest Burgess ${ }^{1}(1925)$ who elaborated it on the ground of history of Chicago city in the last decade of the 19th century (Hoyt, 1939). This theory is based on observation of a city development and it demonstrates that a city is built out from center. Burgess evaluates situation at time of community evolution as well as urban evolution, and divides an urban area into five zones: central business district (CBD - 1) as the center of urban activity and the main point of urban transportation infrastructures, the transition zone of mixed residential and commercial areas with residential places, zone of factories and working class houses located in less convenient and attractive areas, then a better quality middle-class homes zone with newer and better flats, and finally, an fringe suburban zone (Samson, 2001).

To some extent, Burgess' model of concentric zones is a copy of a model by Homer Hoyt who worked out a theory of wedge or radial sector based on urban field usage. Though this model affects placing of factories only partially, it succeeds to describe trends of segregation of different social-economy groups and introduces the so called wedge sectors of dominant usage of urban areas. All that was based on a relatively longterm investigation of prices of rent in different urban districts. Usage of land for living, culture and mainly to agriculture and industrial purpose derived from that.

Development of industrial parks must pay attention to one of the basic aims of an economy, that is to allocate both industrial production and services sector in such a way, that progress of a region where a park is built improves. Incorrect allocation results in an increase of existing differences among various regions, which is verified by regional development theories, be they convergent or divergent. The former ones (theories of regional balance), which say that the basic condition of development lies in balancing off diferences among regions, prove that more developed regions accumulate capital faster and better, which leads to decrease in marginal product of capital and thus to lower profits. Hence, funds flow into regions insufficient with capital and therefore, the yield is even lower. The operating factor of workforce then migrates to more developed

\footnotetext{
${ }^{1}$ Ernest Watson Burgess 16. May 1886 - 27. December 1966 was an urban sociologist at the University of Chicago. Such kind of socilogy takes care about life in cities, structure, processes and problems about urbanism and provides outputs for planning and forming of policies.
} 
countries where salaries are higher. Convergence among various regions in terms of production per a citizen then happens thorough the mechanism of converging of differences in production factors (Buček, Kováč, 2008). Divergence theories (theories of a regional disproportion), on the other hand, consider regional differences to be the necessary and inevitable condition for growth and progress. The main reason for of a disbalanced development is a natural disproportion of economic development among regions, further supported by specialization and concentration (Sloboda, 2006). The theory of polarized development, presented by J. R. Friedman, who brings new term "core - periphery" and justifies its status in development process, is one of divergence theories. According to this theory, level of its autonomy, dependency on other regions and ability of innovation transfer is a significant attribute which distinguishes between regions of core and periphery. In core regions, development brings capital which changes economy structure faster and such regions have influence to periphery regions, which has a positive impact on overall economy growth (Friedmann, 1972). As written above, on the one hand, economy policy could focus on erasing differences among regions, however, it should not suppress the character of a particular region by illogical and insensitive building an industrial park, followed by allocation of production and services. Convergence a divergence theories show development of regions in time and have a very strong neoclassic background.

Current theories of regional development, which are classified as institutional theories, have their bases in theories elaborated earlier and accentuate the need of supporting creation of mainly small and medium-size companies, supporting transfer of innovation (because small and medium size companies are able to quickly react on business needs of market), creating and changing business climate in region. However, in relation with the transfer of innovation, these have not got enough sources to bring innovation into practice and therefore, their existence depends on big companies. On the other hand, innovation processes in a region are affected by social-economic specialization of regions, by development of industrial parks or research and development laboratories.

Industrial parks underwent several steps of development and we can talk about few generations of industrial parks. Typically, the first generation of industrial parks, which were built in the 1970s, can be distinguished from the other generations by assembly halls and storages and a rather simplistic architecture. The area of administrative buildings took about only 10 to 15 per cent of the total area of the park. In the period between 1975 and 1985, industrial parks where offices, which were used by companies dealing with science, technologies and business, occupied much larger space. Characteristic for this second generation industrial parks was a challenging and more complicated architecture. Since the second half of the 1980s, the third generation industrial parks was built; these were typical by elastic use of the area and a wide portfolio of services, as well as by an increase in the number of administrative staff and furthermore, more space was offered to offices focusing on IT. Administrative buildings and wide portfolio of services was characteristic for fourth generation industral parks which begun to arise from the mid-1990s. Companies located in the parks used high-end technologies, storage houses were usually located outside the park itself and there was an increase in the importace of recreational areas connected to the park that were used by people working in them. Since the second half of the 1990s, industrial parks have been a part of an international network of cooperating parks. 


\section{Progress of industrial parks in Europe, their positives and negatives}

The cornerstone of industrial parks can be found in Great Britain, which is a country, where factory production spread and where first industrial zones were founded. These were set up by multiple production units; the first factories arose somewhat accidentally, however, their later occurrence represents an organized deed that followed certain idea of urban planning and regional concept. The first industrial park, Trafford Park, was established by a company named Shipcanal and Docks near Manchester in 1896.

Industrial parks, whose emergence was motivated by concepts of regional policies, were being founded in crisis areas of Great Britain in the 1930s; there was 46 of them in 1960. The first, pioneering industrial areas were in cities such as Letchworth or Welwyn and we can even found their predecessors - Victorian settlement models such as Bournville, New Earswich and Port Sunlight. An expansion of new cities was first motivated by a necessity to reconstruct residential buildings and to relieve the over-saturated London agglomeration (e.g. building of new city of Milton Keynes). It was also important for location of industries within Great Britain (Samson a kol., 2001). Industrial parks in those days varied in both character and size; they ranged from parks, area of which occupied a few acres and which had little or no equipment at all, to huge parks, stretching on the area of a couple of hundreds acres and equipped with technical and social infrastructure built by the park owner. They had a common feature: the area was planned in advance and individual producers had to follow the plan (Keppl, 2002). There were acts which were intended to regulate the location of a particular industry to exact districts (Acts of 1945, 1950 and 1958). The act about location of industry, which was passed in 1958, dealt with high unemployment, or with the threat of it, to be more precise, and by financial help to areas affected by unemployment. Such Acts of industry location were nullified by the Local Employment Act from 1960.

Industrial parks were being established in Germany, too, and the first industrial park was set up in 1963 (Euro-Industriepark Munchen). Greater number of industrial park and parks for small and medium size industrial companies emerged no sooner than in the second half of the 1980s and it was basically an initiative of public investors. There were 22 industrial and investment parks in West Germany in 1984. Apart from these, private parks were set up as well. These emerged in densely populated areas, were significantly smaller when it comes to their acreage and focused on different market areas. The region which was abundant with such types of parks was for example the Dussseldorf region (23 completed projects in 1992) and the Frankfurt am Mein region (19 completed projects in 1992). Their development is still on nowadays. Industrial parks have undoubtedly a positive impact on business in a country where they are located. They are beneficial in the fact that they apply modern technologies and innovations in production processes, in production of high-end goods, support of innovations and in the fact that they (in)directly improve research capacity of a particular country. A country furthermore profits from foreign companies located in the parks, as these bring economic and innovative potential to a country or internationally well-proven know-how, and thus support the process of reconstruction and modernisation of industry and simultaneously, cover the high deficit balance of trade. Another positive aspect of an existence of an industrial park is that it creates conditions for development of small and medium size companies and their cooperation with foreign economic subjects, and therefore, have a positive effect on copetitiveness ability, 
labour productivity and increase of employment. By this, the aim defined by the European Council at Lisbon in 2000 - that by 2010, the EU must become the most competitive and dynamic knowledge-oriented economy in the world, capable of longterm (environmental) growth and of creation of more numerous and better working places with higher social cohesion. The idea to create European research area brought forward by Commission in Creation of European Research Area ${ }^{1}$ is one of the key elements of the Lisbon Strategy.

After the revision of the Lisbon strategy that was carried out in 2004, the Commission proposed a set of steps focused on an increase of efectivity of public support to the research and development and technology innovations, career growth of research stuff, combination of public and private research, improvement of conditions for research and innovations, intellectual property protection, a correct setup of research products and knowledge market regulations, improvements of competitive rules and development of finance markets and fiscal area.

If we consider that the Lisbon strategy is aimed on Europe hopefully becoming the most competitive economy based on knowledge and know-how, industrial parks are one of the possible ways how to reach the interconnection of science and the practice, which implies the necessity of education, specialized preparation and business initiative or employability of a university graduate. In 2006, the European Commission first stated that creative industries in European Union produce approximately $2.6 \%$ of the EU GDP, which represents more than 500 billion Euro per year, and means employment of more than 5 million highly qualified employees in Europe. Therefore, from the perspective of economy, it is a very important issue and not a mere amendment to the overall area of employment and economy growth. ${ }^{2}$

The influence of industrial parks on overall development of a region is also important. It is obvious that industrial parks cannot be expected to bring immediate results, nonetheless, we can predict that the job opportunities created or transfer of technologies among companies will bring about synergic effects. A concentration of certain types of companies could bring other investors to the region, which can have effect of necessity of housing and services for new employees.

\section{Creation and development of industrial parks in Slovakia}

Before we focus on building of industrial parks in Slovakia, it is necessary to say that their development begun in the period of the former Czechoslovakia (i. e. what is referred to as "the First Republic - ČSR") and was directly connected to development of industry which simultaneously faced several negative influences. These included predominantly transportation; problems were caused by a slow finishing of the railway network and very high prices of railway transport. The reconstruction of the until then underdeveloped road network was sped up only in the last years of the existence of Czechoslovakia when reconstruction of power distribution and communication networks was carried out as well. Motivated by the prospect of large government

\footnotetext{
${ }^{1}$ http://www.euractiv.sk/veda-a-vyskum/zoznam_liniek/investicie-do-vyskumu

${ }^{2}$ FIGEL, J.: Cooperation of companies and universities should be long term and not ad-hoc. Retrieved from http://www.euractiv.sk/lisabonska-strategia/interview/jan-figel-spolupraca-firiema-univerzit-ma-byt-stala-nie-nahodna-video-012721
} 
contracts, big companies started to build what could be considered to be bases of new industrial parks, especially in the western part of Slovakia. Because of the military conjucture and application of certain economic measures between 1939 and 1945, this industrial tidal wave grew even more intensive. The following years saw the key industries being concentrated into a single area, that is to the outskirts of a town, where the "owner" of the land (understand: the state) started to build basic infrastructure: buildings, transportation connections ${ }^{1}$ and connections to the power network (Hallon, 1999, pp. 289-331).

In the 1960s and 1970s, the Research institute of development and architecture in Brno (Výzkumný ústav výstavby a architektury v Brně) in cooperation with URBION, the State institte of urbanism and area development (Státní institut urbanismu a územního rozvoje) published Fundamentals and rules of urban planning (Zásady a pravidla územního plánování, 1983) which divides industrial parks into several categories according to their size: 1) production group taking up less than 2 ha; 2) production district taking up 2-30 ha; 3) industrial inner city district taking up 50-100 ha; 4) peripheral industrial district taking up 80-200 ha; and 5) non-urban industrial district taking up to 1000 ha, with population 60 to 120 workers on 1 ha. At the end of the 1980s, URBION published Rules of urbanite projecting of regional-production groups (Zásady urbanistického projektování územně-výrobních seskupení) which was a very important deed from the perspective of selection of industrial parks locations and which influenced mapping and evaluation of existent state of industrial, development and storage capacities in Slovakia.

The proposal to build industrial parks as leasable production and non-production areas in Slovakia (in Bratislava) was expressed by Swedish company Puntken AB in 1991. Until then there was no specific interest in problems of industrial parks. During preparation of urban plans of Higher Territory Area (Vyšší územný celok - VUC) in 1998, new areas for development of industry and industrial parks were proposed.

As enterpreneurship, business, international movement of capital and mainly foreign investments developed and started to flow into the under-financed Slovakian economy, it was necessary to focus on creation of conditions favourable to influx of foreign investment, such as was the process of preparation of Industrial park act and economy recovery. In hand with development of business, international movement of capital and mainly foreign investments it was necessary in under-financed economy to focus on creation of conditions for foreign investments as. The current Slovak legislation offers many possibilities to create industrial parks as a part of industrial zones defined by and in approved urban-planning documents of cities and communities which is based on the Act about industrial parks, approved by the Slovakian National Parliament on July $1^{\text {st }}$, 2001. The Act No.193/2001 About support of industrial parks creation and with amendment of the Act No. 180/1995 About some steps of adjustment of land ownership with relation of other rules, issued by the Slovakian National Parliament, prepares conditions for support offer to creation of industrial parks, as well as acting of government authorities in such support and future control of this support.

\footnotetext{
${ }^{1}$ It was very effective, almost all factories in Slovakia have been built in areas with train connections.
} 
Before the Act of National parliament of Slovak republic No. 193/2001 About industrial park creation support, amended by No. $156 / 2003$ and 542/2004, there was the Resolution of the Government of the Slovak Republic No.1039 from December, 13, 2000, aim of which is to prepare selection study for industrial parks location within Slovakia. The Act of National parliament of Slovak republic No. 193/2001 About support of industrial park creation defines an industrial park as an area located by urban plan of community (city or village) or area plan of zone, where is ongoing or planned industrial production or services of one or more business units. An industrial park is established by community or regional government of Higher territory area (VÚC) on its own land and it should be equipped with basic infrastructure (water, gas, electricity, transportation network, telecommunication networks, drainage etc.) with ordered ownership and without any tax at place bigger than 2 ha with number of employees more than 200.

The process of foundation of an industrial park must respect Act No. 24/2006 About effects on environment, Act No. 50/1976 About regional planning and building rules in future rules wording, Act No. 127/1994 About review of affection on environment, Act No. 162/1995 About o real estate register and writing of real estate ownership claims (Real estate act /Katastrálny zákon), Act No. 175/1999 About steps necessary for new important investment preparation, Act No. 180/1995 About steps needed to organize real-estate ownership, Act No. 193/2001 About industrial parks creation support, Act No. 220/2004 About protection and usage of land intended for use in agriculture, Act No. 245/2003 About integrated prevention and control of environmental contamination, Act No.. 554/2003 About real estate transfer tax, Scheme of environmental affection judgment (Schematizovaný postup pri posudzovaní vplyvov na životné prostredie), Regulation 82006 - Regulation of industrial park preparation application (Usmernenie k žiadosti na prípravu priemyselných parkov), Regulation 132004 - Regulation of industrial park preparation application (Usmernenie $\mathrm{k}$ žiadosti na prípravu priemyselných parkov).

The previous part of the article defined the term industrial park. The Act of National parliament of the Slovak Republic No. 193/2001 About support of industrial parks foundation, in $\S 3$ presents a set of grants available for communities on condition that they fulfill conditions of $\S 4$. These are grants from the national budget for technological equipment necessary to build industrial park, reimbursements for land which could be claimed for the foundation of the park, transfer to new owner, rent or exchange of estates dedicated to industrial park, including costs connected with the transfer of the land owned by Slovak estate fund into the ownership of communities according to a special regulation, and payment of costs connected with rent of such a land that are carried by a community, or an exchange of these areas with a community, payments for taking a land out of the agriculture land fund and forest land fund. ${ }^{1}$

\footnotetext{
${ }^{1}$ Based on Act of National parliament of Slovak Republic No. 193/2001 About support of industrial park fundation, technological equipment necessary for industrial park comprises of foundation like repositories and water feeding networks, drainage, cleaning and releasing of wasted water, electricity networks including displacement of distribution units and connections, masts and transforming stations etc.
} 
A grant to a community aimed at infrastructural equipment that is necessary for creation of an industrial park could reach up to 70 per cent of the total costs proposed, and the height of these costs is determined according to a special directive on the basis of public acquisition. The subsidy for the compensation of deprivation, purchase of the land and for costs connected to transfer or substition of a land intented for an industrial park can go up to 70 per cent of the price of the land which is determined on the basis of a pricing rule, or 70 per cent of the rental consts (in case of renting) paid duringthe first ten years of the existing renting contract. A grant for payment connected to ablating soil out of agricultural or forest lands can reach up to 70 per cent of the total costs of the transfer. Nonetheless, there is no legitimate and legal claim to the grants whatsoever.

Apart from the grants mentioned, the Slovakian government provides support in setting up of industrial parks and expansion of business; in Slovakia, this support is based on Act No. 56/2009, valid from April 1, 2009, which changes and amends the Act No. 561/2007 About investment support and about some changes and renewal of some acts (valid from January 1, 2008). The Act No. 561/2007 About support of investment was replaced by Act No. 565/2001 About investment stimulus and State support scheme of regional development (Schéma štátnej pomoci na podporu regionálneho rozvoja) No. 1621/2007-1000. Based on that act, regional investment support and support of employment in investment projects is provided, as well as support of industrial production expansion projects, technology centers, strategy services centers and complex centers of travelling.

The rules of individual state support are based on a new principle of higher transparency, objectivity and flexibility of process investment stimulus allocation. The fundamental principle of such new concept comprises in dividing Slovakia into zones which are based on their level of unemployment. The Red zone represents regions with unemployment lower than $10 \%$, the Yellow zone stands for regions with level of unemployment between $10 \%$ and $15 \%$, and finally, the green zone indicates regions with unemployment higher than $15 \%$ as measured by unemployment offices. Investments allocated to regions with higher level of unemployment have higher support level by the government. The next rule set was to differentiate investments by added values of projects that were subsequently divided in the following way: A type project - investments to the processing industry and distribution-logistic centers; B type projects - projects in high-tech sectors and in those with sector externalities (with positive impact into other sectors), as well ascenters of strategic services; and $C$ type projects - research and development centers, technology centers - centers of technology development.

Table No. 1: State support in SR between 2000-2007

\begin{tabular}{|l|c|c|c|c|c|c|c|c|}
\hline Year & 2000 & 2001 & 2002 & 2003 & 2004 & 2005 & 2006 & 2007 \\
\hline $\begin{array}{l}\text { Amount of state support (in } \\
\text { bil. Sk) }\end{array}$ & 11.1 & 7.1 & 6.1 & 6.9 & 9.2 & 10.3 & 9.6 & 7.8 \\
\hline $\begin{array}{l}\text { Amount of state support (in } \\
\text { bill. Sk) }\end{array}$ & 368.5 & 235.7 & 202.5 & 229.0 & 305.4 & 342.6 & 317.7 & 258.9 \\
\hline
\end{tabular}

Source: Ministry of finance $S R$.

The negative aspect of construction of industrial parks in Slovakia is the fact that all activities connected to it boil down to preparation of infrastructure of an area without 
any more tangible and systematic idea of its future function or development. Except for a couple of cases, new areas that are suitable to be included into an industrial zone are found at first, however, this is done without local authorities, which cooperate on modification of the area, not having any clearer idea about which industries or specializations are needed or beneficial in the given region.

It is an analysis of options and competitive advantages of a particular region, alongside to defining business intentions, that represents a substantial competitive advantage. If a project for construction of an industrial park is linked with a clearly defined goal and intention, it is much easier to carry it out in practice and reality (starting with marketing and finishing with technical arrangement of the chosen location). The fact that lots of industrial parks have been set up on a very fertile land and without any long-term conception of development, is another negative related to newly built industrial parks. When one says "industrial park", many people relate it to a fenced area with a few production building made of sheet steel, and nowadays, in the time of economic crisis can we see that these are not used at all and are free to let, the parks are empty and the fertile land has turned into a fallow one. And what is even more important - jobs and working opportunities are being wound down.

Table No. 2: List of industrial parks in Slovak republic

\begin{tabular}{|c|c|c|c|c|}
\hline$\underset{\Xi}{\stackrel{\Xi}{\Xi}}$ & Name of the park & 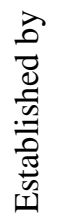 & $\begin{array}{c}\text { Spread } \\
\text { in ha }\end{array}$ & Established investors \\
\hline TT & Senica & M & $190+14 *$ & $\begin{array}{c}\text { Delphi Automotive systems } \\
\text { Slovensko, s.r.o., Slovenský } \\
\text { hodváb, a.s., Slovkord, a.s., Arcelor }\end{array}$ \\
\hline BA & Devínska Nová ves & $\mathrm{S}$ & 11.32 & $\begin{array}{c}\text { SAS Automotives, Eurofit, } \\
\text { Faurecia, Gruppo Antolin, SDC }\end{array}$ \\
\hline TT & Sládkovičovo & $\mathrm{S}$ & 30 & $\begin{array}{l}\text { Bekeart Slovakia, s.r.o., Monzolit- } \\
\text { Fibron, s.r.o., Madea-S, s.r.o. }\end{array}$ \\
\hline TT & Sered' & M & $16.4+9.9 *$ & FM Slovenska, Semmerlock \\
\hline TT & Hlohovec & $\mathrm{M}$ & 12 & Faurecia, Peter Vetter \\
\hline $\mathrm{TT}$ & Šamorín & $\mathrm{S}$ & 9 & Industry association Vicenza \\
\hline TT & Skalica & $\mathrm{M}$ & 1.9 & INA, Protherm \\
\hline TT & Galanta - východ & $\mathrm{S}$ & 33.3 & $\begin{array}{c}\text { Samsung Electronics Slovakia, } \\
\text { Jasplastik, Pedrazolli Slovakia, } \\
\text { Number of SMEs }\end{array}$ \\
\hline TT & Trnava & $\mathrm{S}$ & 18 & $\begin{array}{l}\text { PSA Peugeot-Citroen, } \\
\text { Current Tenants - Gefco, Faurecia, } \\
\text { Datalogic, Sofitec, Premier, Inergy, } \\
\text { Valeo, Magna Donnely, }\end{array}$ \\
\hline TN & Myjava & M & 16 & $\begin{array}{l}\text { SF FIX SK a.s., KODRETA s.r.o., } \\
\text { CEP Scherdel s.r.o. }\end{array}$ \\
\hline TN & Prievidza & $\mathrm{M}$ & 47.2 & Rubig \\
\hline $\mathrm{TN}$ & Trenčín & $\mathrm{M}$ & 117 & AL 1000 s.r.o., CEMMAC a.s., \\
\hline
\end{tabular}




\begin{tabular}{|c|c|c|c|c|}
\hline$\underset{\Xi}{\stackrel{\Xi}{\Xi}}$ & Name of the park & 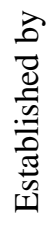 & $\begin{array}{l}\text { Spread } \\
\text { in ha }\end{array}$ & Established investors \\
\hline & & & & $\begin{array}{c}\text { Continental Matador s.r.o., } \\
\text { Emerson a.s., Považský cukor a.s., } \\
\text { Sauer Danfoss a.s., Vetropack } \\
\text { Nemšová, s.r.o., Yazaki Debnar } \\
\text { Slovakia s.r.o. }\end{array}$ \\
\hline NT & Levice - Geňa & $\mathrm{M}$ & 51.64 & $\begin{array}{c}\text { Levitex, a. s., Levicke mliekarne, a. } \\
\text { s., Ido Klein, a. s., Levice, PM } \\
\text { Paksi Marian }\end{array}$ \\
\hline NT & Vráble & $\mathrm{S}$ & 4 & $\begin{array}{l}\text { TELEFLEX, Matador Automotive } \\
\text { Vrable, HEFRA, TESGAL, } \\
\text { Plasmet, JUWA, Semecs s.r.o., } \\
\text { MIBA Slovakia s.r.o. }\end{array}$ \\
\hline NT & Nitra & $\mathrm{M}$ & 210 & $\begin{array}{c}\text { Air Liquide, s.r.o., Visteon } \\
\text { Slovakia, s.r.o., Giesecke and } \\
\text { Devrient Slovakia, s.r.o., } \\
\text { Carnitech/Marel, s.r.o., Matador } \\
\text { Automotive Vráble, a.s. }\end{array}$ \\
\hline NT & Zlaté Moravce & $\mathrm{M}$ & 24 & $\begin{array}{c}\text { Danfoss, Rentals, NPLS, Estamp, } \\
\text { Wienerberger - Slovenské tehel'ne, } \\
\text { s.r.o. }\end{array}$ \\
\hline $\mathrm{BB}$ & Poltár & $\mathrm{M}$ & $24.5+8 *$ & $\begin{array}{c}\text { Avant, a.s., Lunaco, s.r.o., Lute, } \\
\text { a.s., Ipel'ské tehel'ne, a.s. }\end{array}$ \\
\hline $\mathrm{BB}$ & Krupina & $\mathrm{M}$ & $20+5^{*}$ & \\
\hline $\mathrm{BB}$ & Lučenec & & 20.8 & $\begin{array}{c}\text { Johnson Controls, Mäso-spracujúca } \\
\text { a drevo- pracujúca spoločnost' } \\
\text { Jackuliak }\end{array}$ \\
\hline $\mathrm{BB}$ & Tomášovce & $\mathrm{M}$ & $30+67 *$ & $\begin{array}{c}\text { Logistic centre of Austrian } \\
\text { company, Agrotom s.r.o., ACHP, } \\
\text { s.r.o., Orichtolagus s.r.o., B.B.S. } \\
\text { Slovakia s.r.o., }\end{array}$ \\
\hline $\mathrm{BB}$ & Malý Krtíšs & $\mathrm{S}$ & 20 & $\begin{array}{l}\text { LIAZ Vel'ký Krtíš, Bana Dolina, } \\
\text { Sole Slovakia, s.r.o. }\end{array}$ \\
\hline $\mathrm{BB}$ & Rimavská Sobota & $\mathrm{M}$ & 12 & Detox s.r.o., Area ZTS \\
\hline $\mathrm{BB}$ & Žarnovica & $\mathrm{M}$ & 53 & $\begin{array}{c}\text { Illichman Slovakia, Neuman } \\
\text { Aluminium Fliesspresswerk } \\
\text { Slovakia, Tubex Slovakia }\end{array}$ \\
\hline $\mathrm{BB}$ & Šalková & $\mathrm{S}$ & 35.7 & DOKA, FERMAS, HOLCIM \\
\hline $\mathrm{BB}$ & Detva - Kriváň & $\mathrm{M}$ & 8 & \\
\hline $\mathrm{BB}$ & $\begin{array}{l}\text { Vígl’aš pod } \\
\text { Bachtárom }\end{array}$ & $\mathrm{M}$ & 37.8 & \\
\hline
\end{tabular}




\begin{tabular}{|c|c|c|c|c|}
\hline$\underset{\Xi}{\grave{\Xi}}$ & Name of the park & 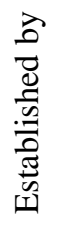 & $\begin{array}{c}\text { Spread } \\
\text { in ha }\end{array}$ & Established investors \\
\hline $\mathrm{ZA}$ & Bytča & $\mathrm{M}$ & 48.58 & DHollandia \\
\hline $\mathrm{ZA}$ & Martin - Sučany & $\mathrm{M}$ & 436 & ECCO, Volkswagen \\
\hline PO & Chemes - Humenné & $\mathrm{S}$ & 64 & $\begin{array}{c}\text { Nylstar Slovakia, a. s., Rhodia } \\
\text { Industrial Yarns, a. s., PJ Bike, s. r. } \\
\text { o., TYTEX Slovakia, s. r. o., VSK, } \\
\text { s. r. o., Prefil Slovakia, s. r. o., } \\
\text { Twista, s. r. o., Strojarne Chemes, s. } \\
\text { r. o. }\end{array}$ \\
\hline $\mathrm{PO}$ & Prešov - Záborské & $\mathrm{S}$ & 26 & $\begin{array}{l}\text { Chemko, Chemza, Cenon (Italy), } \\
\text { Whirpool, s.r.o., Terichem,,a.s., } \\
\text { Tatramat, a.s., Tesla Stropkov, a.s., } \\
\text { Tatravagónka, a.s. }\end{array}$ \\
\hline $\mathrm{PO}$ & Kežmarok & $\mathrm{M}$ & $10+20 *$ & $\begin{array}{c}\text { Tatravagónka a.s. Poprad, } \\
\text { Chemosvit a.s. Svit, Chemkostav } \\
\text { Humenné, Hengstler }\end{array}$ \\
\hline $\mathrm{PO}$ & Poprad & $\mathrm{M}$ & 23 & $\begin{array}{l}\text { Whirpool, s.r.o., Terichem, a.s., } \\
\text { Tatramat, a.s., Tesla Stropkov, a.s., } \\
\text { Tatravagónka, a.s., Chemosvit, a.s. }\end{array}$ \\
\hline PO & Bardejov - východ & $\mathrm{M}$ & 72.3 & \\
\hline $\mathrm{PO}$ & $\begin{array}{c}\text { Vranov nad Topl'ou } \\
\text { - Čemerné }\end{array}$ & $\mathrm{M}$ & 18 & \\
\hline $\mathrm{KE}$ & Kechnec & $\mathrm{M}$ & 80 & $\begin{array}{l}\text { Molex Slovakia, a.s., Gilbos, Swep, } \\
\text { Kuenz, Getrag - Ford, V.O.D.S., } \\
\text { DORSVET, US Steel Košice }\end{array}$ \\
\hline $\mathrm{KE}$ & Strážske & $\mathrm{S}$ & 40 & 17 companies, 2 international ones \\
\hline $\mathrm{KE}$ & Michalovce & $\mathrm{M}$ & 17.6 & $\begin{array}{c}\text { BSH Drives and Pumps, Yazaki } \\
\text { Wiring Technologies Slovakia, } \\
\text { Unomedical }\end{array}$ \\
\hline $\mathrm{KE}$ & Trebišov & $\mathrm{M}$ & $10+60$ & Leonidas, Hobes, US Steel Košice \\
\hline
\end{tabular}

Source: Own table based on data of Ministry of economy SR, SARIO, www.sario.sk

Note: $M$ - city office, $S$ - private establisher, *after planned deveopment.

Influence of industrial parks on the employment in SVK

The importance of industrial parks can be described by analyses of working place creation. The data available (for SVK and its counties) about the number of people employed in industrial parks in SVK, the planned number of people employed in industrial parks, the total number of employees in SVK, the average rate of unemployment, were summarized in the table (see table No. 3) in such a way that we can judge relations between it. On the data available we can see that the highest number of people employed in industrial parks can be found in the Žilina county (4 779 working places), the lowest number in Trenčín county (1 430 working places). When we take 
a look on number of planned working places, the highest number can be found for the Žilina county (6 470 working places). There is a plan to create approximately 3100 working places in other counties. the highest rate of employees in industrial parks from the total number of employees in a county can be found in Košice county (1.64 \%), then Trenčín county $(1.60 \%)$, Prešov county $(1.45 \%)$, Nitra county $(0.90 \%)$, Banská Bystrica county $(0.82 \%)$ and Trnava county $(0.82 \%)$. Significantly lowest rate of employed in industrial parks on overall number of employees in county is in Trenčín county $0.51 \%$.

Table No. 3: Indicators of employment and unemployment in SVK (2008)

\begin{tabular}{|l|c|c|c|c|c|c|}
\hline County & $\begin{array}{c}\text { Employees } \\
\text { of IP }\end{array}$ & $\begin{array}{c}\text { Planned } \\
\text { eployees } \\
\text { in IP }\end{array}$ & $\begin{array}{c}\text { Different } \\
(3-2)\end{array}$ & Employees & $\begin{array}{c}\text { Rate of } \\
\text { employment } \\
\text { in SVK } \\
\text { in \% }\end{array}$ & $\begin{array}{c}\text { Average } \\
\text { rate of } \\
\text { employment } \\
\text { in \% }\end{array}$ \\
\hline 1 & 2 & 3 & 4 & 5 & 6 & 7 \\
\hline Trnava & 2220 & 2975 & 755 & 271300 & 11.5 & 6.5 \\
\hline Žilina & 4779 & 6470 & 1691 & 299200 & 12.7 & 10.1 \\
\hline Trenčín & 1430 & 5130 & 3700 & 278000 & 11.8 & 5.7 \\
\hline Prešov & 4706 & 5499 & 793 & 323900 & 13.7 & 13.8 \\
\hline Košice & 4744 & 4744 & 0 & 288600 & 12.2 & 15.9 \\
\hline Nitra & 2800 & 3100 & 300 & 312400 & 13.3 & 10.7 \\
\hline $\begin{array}{l}\text { Banská } \\
\text { Bystrica }\end{array}$ & 2140 & 2900 & 760 & 259600 & 11.0 & 20.0 \\
\hline Bratislava & 3000 & 4000 & 1000 & 324400 & 13.8 & 4.2 \\
\hline $\begin{array}{l}\text { Slovak } \\
\text { Republic }\end{array}$ & 25819 & 34818 & 8999 & 2357300 & 100.0 & 11.0 \\
\hline
\end{tabular}

Source: Own table based on calculation of SARIO, ÚSP a R data from 2008.

Industrial parks are one of options how to increase employment in regions. Based on data in table 3 , a prognosis about number of working places necessary to reach the average rate of unemployment of $5.0 \%$ or $7.0 \%$ was carried out. To reach the average rate of unemployment of $7.0 \%$, it is necessary to create 106,774 working places, and to reach $5.0 \%$, it is necessary to create 159,767 new working places. In order to reach both $5.0 \%$ and $7.0 \%$ unemployment rate, most working places have to be created in Banská Bystrica county and less in Žilina county.

In relation with creation of new working places, we cannot forget an important need related to the working place, that is the necessity of housing, because there is an absence of available low-cost flat units in the Slovak Republic ${ }^{1}$ (understandmainly rental flats in regions with available working places). Because of insufficient transportation infrastructure, everyday commuting to creates traffic jams and traffic problems.

\footnotetext{
${ }^{1}$ There is on average 308 flats to a thousand inhabitants in Slovakia. The average in EU countires is 485 flats to one thousand inhabitants, though.
} 
Table No. 4: Summary of indicators (2008)

\begin{tabular}{|l|c|c|c|c|c|c|}
\hline County & $\begin{array}{c}\text { Employees } \\
\text { of IP } \\
\text { /Employees }\end{array}$ & $\begin{array}{c}\text { Planned } \\
\text { Employees } \\
\text { of IP / No. } \\
\text { of } \\
\text { employees }\end{array}$ & $\begin{array}{c}\text { Number } \\
\text { of } \\
\text { working } \\
\text { places } \\
\text { necessary } \\
\text { to reach } \\
\text { OVPMN } \\
7.0 \%\end{array}$ & $\begin{array}{c}\text { Number } \\
\text { of } \\
\text { working } \\
\text { places } \\
\text { necessary } \\
\text { to reach } \\
\text { OVPMN } \\
5.0 \%\end{array}$ & $\begin{array}{c}\text { Difference } \\
\text { between } \\
\text { necessity } \\
\text { and reality } \\
\text { of working } \\
\text { places in } \\
\text { case of } \\
7.00 \% \\
\text { unempl. }\end{array}$ & $\begin{array}{c}\text { Difference } \\
\text { between } \\
\text { necessity } \\
\text { and reality } \\
\text { of working } \\
\text { places in } \\
\text { case of } \\
5.00 \% \\
\text { unempl. }\end{array}$ \\
\hline Trnava & $0.82 \%$ & $1.10 \%$ & 269849 & 275652 & -1451 & 4352 \\
\hline Žilina & $1.60 \%$ & $2.16 \%$ & 309517 & 316174 & 10317 & 16974 \\
\hline Trenčín & $0.51 \%$ & $1.85 \%$ & 274168 & 280064 & -3832 & 2064 \\
\hline Prešov & $1.45 \%$ & $1.70 \%$ & 349451 & 356966 & 25551 & 33066 \\
\hline Košice & $1.64 \%$ & $1.64 \%$ & 319141 & 326005 & 30541 & 37405 \\
\hline Nitra & $0.90 \%$ & $0.99 \%$ & 325344 & 332340 & 12944 & 19940 \\
\hline Banská & $0.82 \%$ & $1.12 \%$ & 301785 & 308275 & 42185 & 48675 \\
\hline Bystrica & $0.92 \%$ & $1.23 \%$ & 314919 & 321691 & -9481 & -2709 \\
\hline Bratislava & $1.10 \%$ & $1.48 \%$ & 2464174 & 2517167 & 106774 & 159767 \\
\hline Sum & & & & & & \\
\hline
\end{tabular}

Source: Own table.

Note: OVPMN - Optimistic variant of average unemployment rate.

Graph No. 1: Rate of unempolyment in counties (2008)

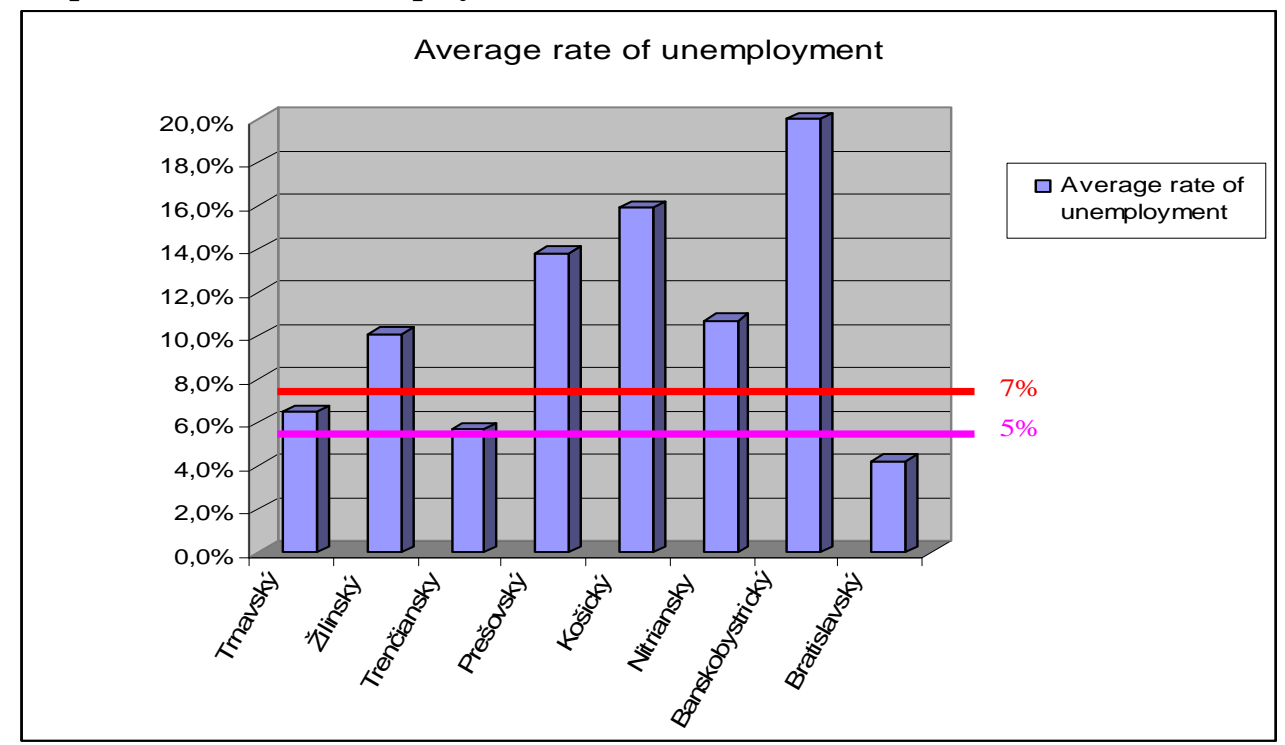

Source: Own graph based on data from tables No. 2 and 3. 


\section{Graph No. 2: Working places}

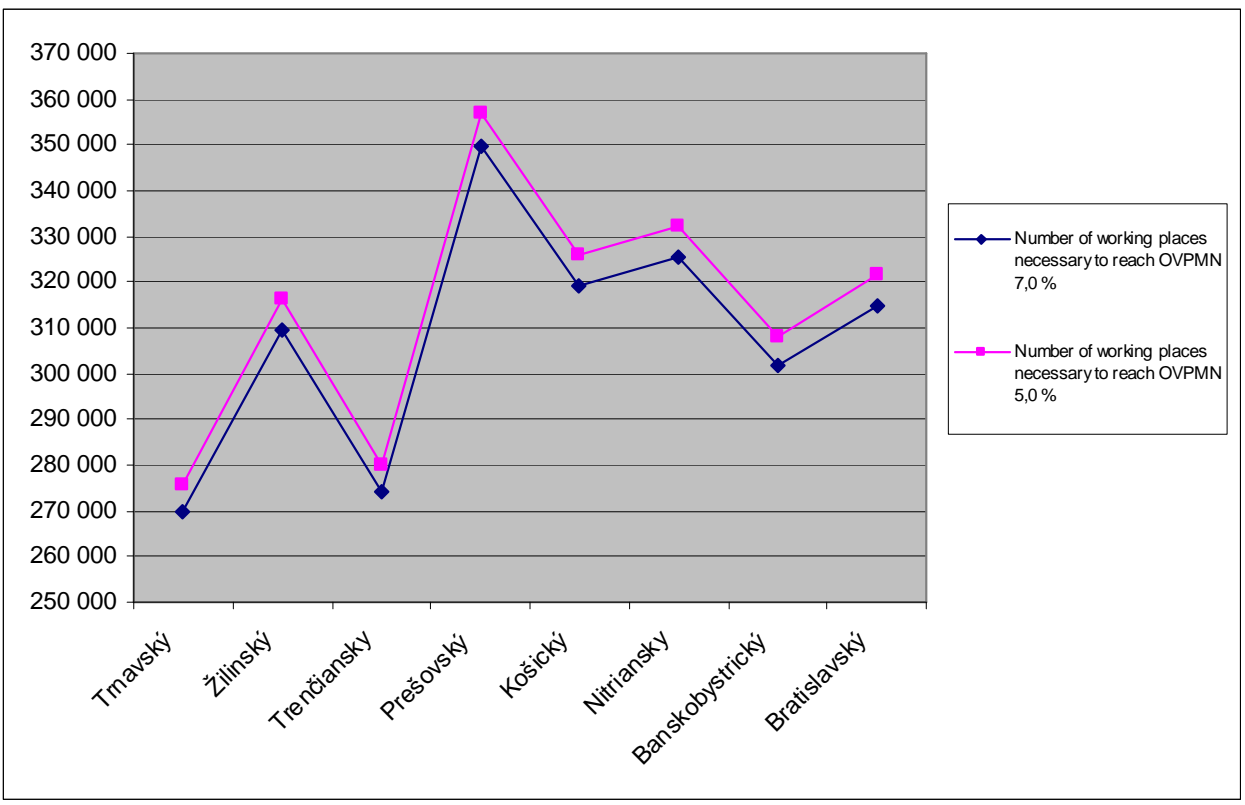

Source: Own graph.

Graph No. 3: Number of working places necessary to reach OVPMN 7.0 \% versus Number of working places necessary to reach OVPMN 5.0\%

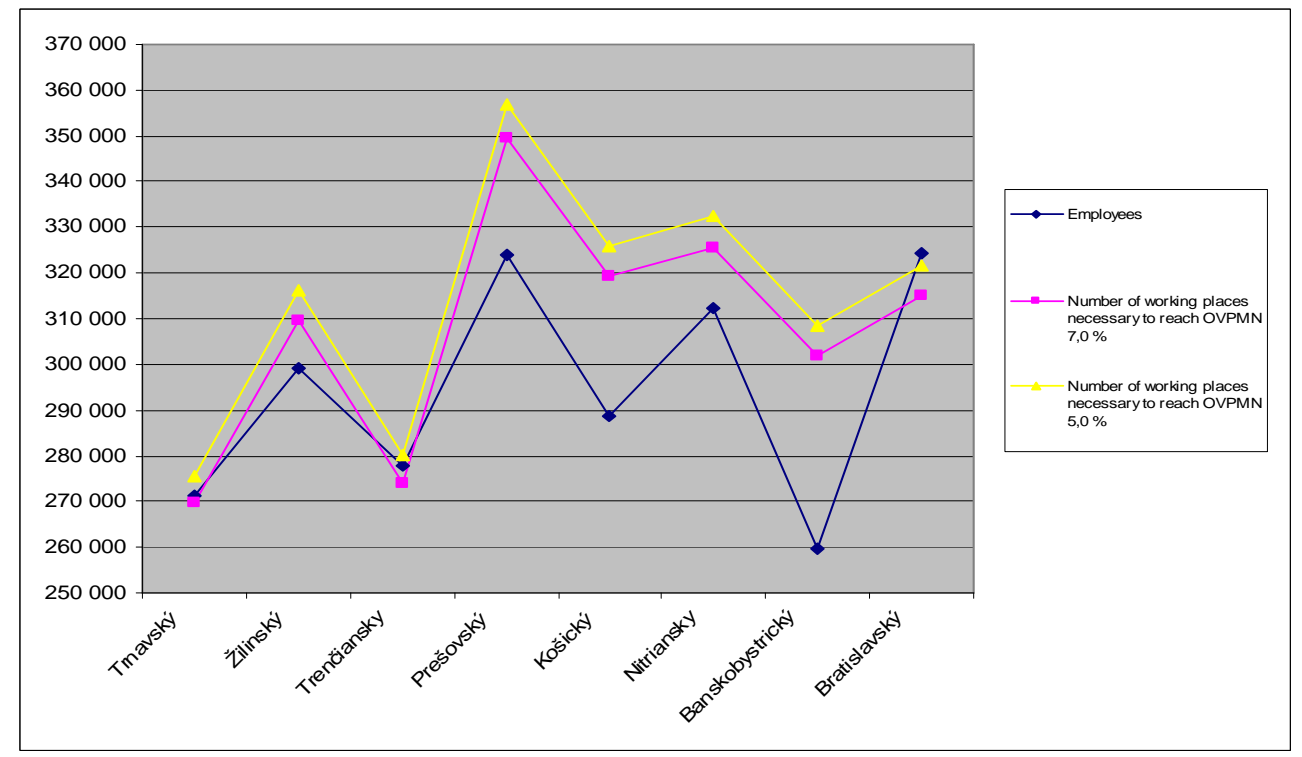

Source: Own graph.

Note: lower line - number of unemployed in rate of 11,0\%. 


\section{Resume}

On the basis of Resolution of European Parliament about advocacy of the Lisbon Programme of the Community it was decided that research and innovation should be supported: greater degree of investment into employment growth: common steps (2006/2005/(INI)) that pay attention to the Commission of Advocacy of the Community's Lisbon Programme: greater degree of research and innovation investment into employment growth: common steps (KOM (2005) 0488) and other accompanying documents, and furthermore, the importance of industrial parks and areas of innovation on regional level and their interconnection with corresponding structures in other regions both in member and third-party countries was acknowledged.

When it comes to the the process of industrial parks development, the importance is put on an ideal placement of critical production investments, which takes place on the basis of disinterested localization criteria. It is necessary to enforce cooperation not only on the level of large territorial units and among individual production activities and other functional units of urban structures but also among indivual sectors of production. This should be applied to those cases when a foreign investor brings supplier structures into the area. One of the crucial economic viewpoints should include preference of utilization of existing unused or less effective industrial zones. If a foundation of an industrial park in new areas, is inevitable to do so in areas that are unproductive or less profitable from the agricultural point of view, or in forested areas.

Industrial parks represent a factor which has certain influence on the economy growth. It creates conditions that help important foreign investors to establish themselves in many countries. In Slovakia, industrial parks have a positive influence on revitalization of business environment, transfer of modern technologies, or helped restructuralisation and modernization of industry. The current progress in Slovakia confirms that creation of industrial parks contributed to creation of new working places. Most of the new working places were created in Košice, Žilina and Bratislava counties. In regions where no new industrial parks were created, economic situation is fairly bad and the average rate of unemployment is high; here we are speaking about the Banská Bystrica and Prešov counties. In industrial parks it is necessary to set-up such branches of industry and activities which will support in-country research and development. Those could help selected areas of economy to reach appropriate production and technology innovations and thus support higher competitiveness of our producers. We can consider them to be a part of a new era hierarchy of economy structures, research and innovation activities, as well as an issuereflecting new philosophy of industrial productions. On behalf of fulfilling ideas of this philosophy the government should intervene as well, mainly by directing of demand by stimulation of public or private consumption, or by the way of investment processes support in small and medium-size companies. 


\section{References}

BUČEK, M., KOVÁČ, L. (2008). Regionálna konvergencia resp. divergencia na pozadí teoretických koncepcií. In Zborník prednášok z Medzinárodného vedeckého seminára "Regionální disparity - jejich pojetí, klasifikace a měrení". Ostrava: VŠB - Technická univerzita, Ekonomická fakulta, 2008, ISBN 978-80-248-1890-0.

FRIEDMANN, J. (1972). A General Theory of Polarized Development. 1972, In Hansen, N. M. (ed.): Growth Centres in Regional Economic Development, New York, Free Press, 1966.

HALLON, L' (1999). Technika na Slovensku v rokoch 1918-1945. In Priekopníci vedy a techniky na Slovensku III. diel. Bratislava.

HOYT, H. (1939). The Structure and Growth of Residential Neighbourhoods in American Cities Washington, Federal Housing Administration.

KEPPL, J. (2002). Prenajímatel’né priemyselné územia vo Vel'kej Británii. Životné prostredie. 4. ISSN 0044 - 4863.

KOZOVÁ, M. (2002). Budovanie priemyselných parkov v Slovenskej republike, ich právne zabezpečenie a koncepcia umiestnenia. Životné prostredie. 4, 2002 ISSN 0044 4863.

LESÁKOVÁ, L. (2006). K otázke budovania priemyselných parkov v Slovenskej republike. Ekonomika a spoločnost'. roč. VII, č.2, ISSN 1335-7069.

MIKULEC, V. (2000) Investície v ekonomickom rozvoji a priemyselný park ako faktor dynamiky investovania. In Zborník príspevkov výskumných prác KHP NHF EU Transformácia ekonomiky SR. Bratislava: Sprint.

SAMSON, Š. a kol. (2001). Regionálna ekonomika. Košice. ISBN 80-7099-716-8.

SLOBODA, D. (2006). Slovensko a regionálne rozdiely. Bratislava: Konzervatívny inštitút M. R. Štefánika.

FIGEL', J. Spolupráca firiem a univerzít má byt’ stála, nie náhodná. Euractiv 28.4.2009.

MH SR (2001). Manuál pre poskytovanie podpory na zriad’ovanie priemyselných parkov. Retrieved from http://www.economy.gov.sk .

Evropská komise. Oznámenie Komisie s názvom "Investovanie do rozvoja: akčný plán pre Európu" (KOM(2003)0226).

Evropská komise. Oznámenie Komisie jarnej Európskej rady s názvom "Spoločne pracujeme na hospodárskom raste a zamestnanosti - nový začiatok lisabonskej stratégie" $(\operatorname{KOM}(2005) 0024)$.

Schematizovaný postup pri posudzovaní vplyvov na životné prostredie.

Smernica 82006 - Usmernenie k žiadosti na prípravu priemyselných parkov.

Smernica 132004 - Usmernenie k žiadosti na prípravu priemyselných parkov.

Správa o zabezpečení vypracovania "Štúdie pre umiestnenia priemyselných parkov vo vybraných oblastiach Slovenskej republiky. MŽP SR, 2002. 
Štúdie pre umiestnenie priemyselných parkov vo vybraných oblastiach Slovenskej republiky. MŽP SR, 2002.

Uznesenia Európskeho parlamentu o presadzovaní lisabonského programu Spoločenstva: viac výskumu a inovácií - investovanie do rastu a zamestnanosti: spoločný postup (2006/2005(INI))

Zákon č. 24/2006 Zb. o posudzovaní vplyvov na životné prostredie.

Zákon č. 50/1976 Zb. o územnom plánovaní a stavebnom poriadku (stavebný zákon).

Zákon č. 127/1994 Zb. o posudzovaní vplyvov na životné prostredie.

Zákon č. 162/1995 Zb. o katastri nehnutel’ností a o zápise vlastníckych a iných práv k nehnutel'nostiam (Katastrálny zákon).

Zákon č. 175/1999 Zb. o niektorých opatreniach týkajúcich sa prípravy významných investící́.

Zákon č. 180/1995 Zb. o niektorých opatreniach na usporiadanie vlastníctva $\mathrm{k}$ pozemkom.

Zákon č. 193/2001 Zb. o podpore na zriadenie priemyselných parkov.

Zákon č. 220/2004 Zb. o ochrane a využívaní pol’nohospodárskej pôdy.

Zákon č. 245/2003 Zb. o integrovanej prevencii a kontrole znečistovania životného prostredia.

Zákon č. 554/2003 Zb. o dani z prevodu a prechodu nehnutel'ností.

http://www.euractiv.sk/lisabonska-strategia/interview/.

Materiály Ministerstva hospodárstva SR, dostupné na www. economy.gov.sk.

www.sario.sk.

\title{
INDUSTRIAL PARKS - HISTORY, PRESENT AND ITS INFLUENCE TO THE EMPLOYMENT
}

\section{Jarmila Vidová}

Katedra hospodárskej politiky, NHF EU v Bratislave, Dolnozemská cesta 1, 85235 Bratislava 5; e-mail: vidova@ dec.euba.sk

\begin{abstract}
The term industrial park is currently a very frequently used. One of the conditions of their development is a positive trend of capital movement and correct allocation of capital in new conditions of Slovak and world economy. In current postindustrial stage of development, industrial parks grow in quality in comparison of parks built in the past when all the activities of product building were allocated were concentrated into one single place. The new generation of industrial parks is characteristic by producing just one product or completion of final goods from components. The present day development in Slovakia confirms that it is necessary to
\end{abstract}


support creation of industrial parks because it has a positive influence to activities supporting research and development and increasing of employment.

Key words: investment, industrial park, employment.

JEL Classification: E22, E23, 016.

DOI: $10.2478 / \mathrm{v} 10135-009-0008-1$

Picture No. 1 Map of industrial parks in Slovakia

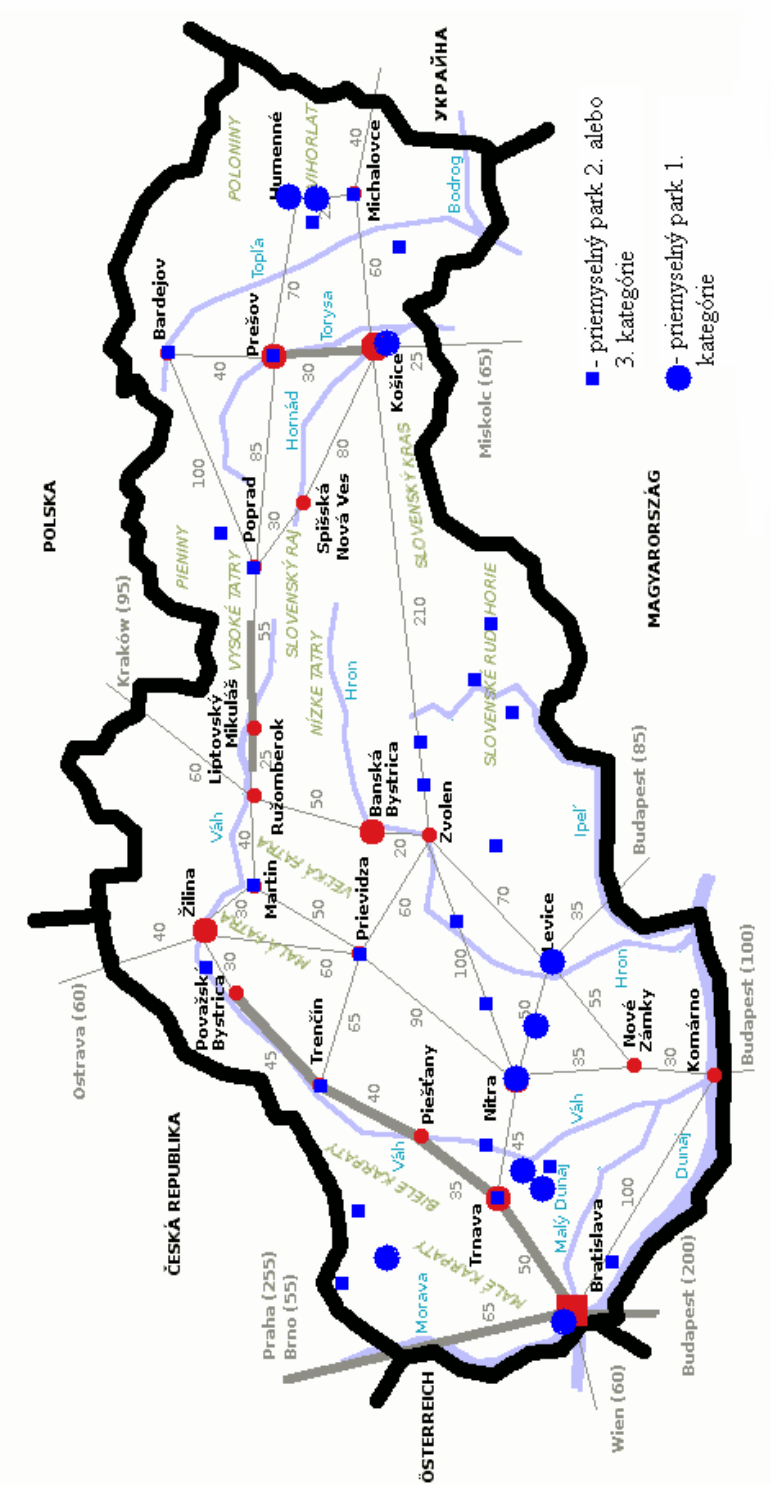

